\title{
Tree Species Composition and Distribution Pattern in a Myristica Swamp of Northern Kerala, India
}

\author{
K.A.SREEJITH* ${ }^{\star}$ U.M.CHANDRASHEKARA, T.K.NIRMESH and V.B SREEKUMAR \\ Forest Ecology and Biodiversity Conservation Division, \\ Kerala Forest Research Institute, Peechi, Thrissur Dt. Kerala, India.
}

http://dx.doi.org/10.12944/CWE.11.3.08

(Received: August 19, 2016; Accepted: September 14, 2016)

\begin{abstract}
Phytosociological studies have been carried out in a Myristica swamp in Northern Kerala to reveal the composition and distribution pattern of different tree species. On the basis of IVI, the family Myristicaceae was dominant and the association is Knema attenuata - Myristica malabarica-Holigarna arnottiana type. The species like Gymnacranthera canarica and Myristica fatua var. magnifica, which are believed to be the essential elements of Myristica swamps, are totally absent here. A total 403 individuals ( $\mathrm{gbh} \geq 10.1 \mathrm{~cm}$ ) were recorded with a basal area of $34.25 \mathrm{~m}^{2} \mathrm{ha}^{-1}$ in $0.5 \mathrm{ha}$. area. Total number of species recorded was 28, which represent 21 families in which Myristicaceae represents $48.18 \%$ of total IVI. Among two dominant species, Myristica malabarica prefer swampy area hence their number of individual shows decreasing trend when we move from the swamp while the second dominant species Knema attenuata showing a reverse trend and was completely absent in the first five quadrats where soil water content is too high. Species specific eco-physiological studies are required to understand the reasons for change in the distribution pattern of these dominant species.
\end{abstract}

Keywords: Myristica swamps, Western Ghats, Tree distribution, Tree composition, Myristicaceae, Myristica malabarica, Knema attenuata.

\section{INTRODUCTION}

Being one among the global biodiversity hotspots, the Western Ghats harbors a diverse of habitats that support unique sets of flora and fauna. Myristica swamps are such a unique wetland ecosystem found in this region. These swamps, as their name indicates are characterised by the dominance of the members of family Myristicaceae represented with species like Gymnacranthera canarica, Myristica fatua, Myristica dactyloides, Myristica malabarica and Knema attenuata. Located in low-lying, poorly drained depressions and characterized with a very long rainy season, these swamps are now restricted only in highly fragmented patches along the Western Ghats. The dominant species or the association among Myristicaceae may vary with respect to locality and microclimate. Myristica swamps were first of all reported by Krishnamoorthy ${ }^{1}$ from the valleys of Shendurney, Anchal and Kulathupuzha in Southern Kerala. According to Champion and Seth ${ }^{2}$ these are placed under 'tropical fresh water swamp forests' whereas Pascal $^{3}$ describes these as 'ripicole facies' (riparian facies). The Myristica swamps of Southern Kerala were highly explored for their vegetation and soil characteristics by several authors ${ }^{4-9}$ whereas in other parts of the state especially that of Northern Kerala, the information was scanty ${ }^{10-12}$. Apart from Kerala, the Myristica swamps were also reported from other parts of the Western Ghats such as Karnataka ${ }^{13-17}$ and $\mathrm{Goa}^{18}$. These threatened ecosystems represent 
red listed species like Semecarpus kathalekanensis, Syzygium trvancoricum as per the IUCN criteria. Most of the studies pertaining to myristica swamps are focused on phyto-sociological aspects including a recently reported one new species, Burmannia championii Thwaites ${ }^{19}$ which point insights towards the unexplored biodiversity in this threatened ecosystem. Here, in the present study, we are trying to gather information on the species composition of a Myristica swamp in Northern Kerala by phytosociological analysis. Since the distribution pattern of dominant species along in Myristica Swamps was not studied earlier, our study will give more focus on this aspect.

\section{MATERIALS AND METHODS}

\section{Study area}

The present study was conducted in a Myristica swamp of Sivapuram, Koothuparambu at Kannur District of Northern Kerala $\left(11^{0} .91967 \mathrm{~N}\right.$ and $\left.75^{\circ} .61612 \mathrm{E}\right)$. The altitude is $70 \mathrm{~m}$ above $\mathrm{msl}$.

\section{Vegetation analysis}

A relatively undisturbed patch of Myristica swamp was selected for the study. Fifty quadrats of $10 \times 10 \mathrm{~m}$ size were established to cover a total area of $5000 \mathrm{~m}^{2}$. The basic data on vegetation such as density, basal area, frequency and IVI were calculated. In order to understand the species distribution pattern, the entire are $\left(5000 \mathrm{~m}^{2}\right)$ was divided into five plots starting from the swamp to away from it. These plots having $20 \times 50 \mathrm{~m}$ size which contains 10 quadrats of $10 \times 10 \mathrm{~m}$ size; hence a total area of $1000 \mathrm{~m}^{2}$ was covered in a plot. All trees having gbh $\geq 10.1 \mathrm{~cm}$ were identified and measured for their gbh. Individuals below $10.1 \mathrm{gbh}$ and height $\geq 50 \mathrm{~cm}$ were counted and recorded as seedlings. The density, frequency, and basal area of individuals (gbh $\geq 10.1 \mathrm{~cm}$ ) were estimated following standard methods $^{20}$. Relative frequency, relative dominance and relative density of each species were calculated to obtain Importance Value Index (IVI) of species ${ }^{21}$. The data were also analysed for species diversity index ${ }^{22}$ and Simpson's index of dominance ${ }^{23}$. In addition, the distribution pattern of species within the study area were studied by comparing the five plots (each of $1000 \mathrm{~m}^{2}$ ) starting from the stream side to away from it. Data were statistically tested using ANOVA.

\section{RESULTS AND DISCUSSION}

\section{Vegetation structure and composition}

The dominant species based on IVI were Knema attenuata, Myristica malabarica and Holigarna arnottiana and about half of the total IVI was contributed by first two species (Table 1). Generally, in swampy ecosystems similar to the study area, the family Myristicaceae is remarkably dominant over other families but the species like Gymnacranthera canarica and Myristica fatua var. magnifica, which are believed to be the essential elements to consider an ecosystem as Myristica swamps ${ }^{24}$, were not recorded in the present study. But, we could not find out any strong reason for such a categorization since the species composition is determined by many factors such as microclimate, soil characteristics, dispersal mechanisms, fragmentation etc. Since the current one is a fragmented sacred grove in a rural area, we may not expect all dominant species characteristic to Myristica swamp ecosystem. Since the vegetation is dominated by the family Myristicaceae and found in a swampy environment with the of knee roots can be considered as Myristica swamp irrespective species composition and contribution within the family.

The density (individuals ha-1) of trees ( $\mathrm{gbh} \geq$ $10.1 \mathrm{~cm}$ ) was 806 and basal area $\left(\mathrm{m}^{2} \mathrm{ha}^{-1}\right)$ was 34.25 $\left(m^{2} h a\right.$.) which is comparable to other studies where it was $520,58.35^{6}$ and $2024,30.14^{4}$ respectively. Most of the trees in the study were represented with lower girth classes which results in low basal area value (Figure 1). The maximum number of individuals recorded from a single quadrat $(10 \times 10$ $\mathrm{m}$ ) was twelve and the maximum number of species recorded was nine. The mean density of 50 quadrats $(10 \times 10 \mathrm{~m})$ was eight and these values were high when compared to other studies [5] where it was 9, 7 and 5.5 respectively. Out of 403 individuals (gbh $\geq$ $10.1 \mathrm{~cm}$ ) recorded, 242 individuals represented the family Myristicaceae.

The values of floristic diversity indices (gbh $\geq 10.1 \mathrm{~cm}$ ) were comparatively less, when compared to diversity indices of semi-evergreen and evergreen forests ${ }^{25}$. In our observation, any minute change in abiotic or biotic factors may affect swampy system and results in change in the structure and composition of tree community. In a Myristica swamp, specific conditions such as water content in the 
soil, presence of knee roots etc. are the reason for few number species and over dominance selected members of Myristicacease which could survive in swampy system. Most of the Myristica swamps in Western Ghats including the present one are highly fragmented to disjunct patches, where the gene flow and seed dispersal is restricted by geographical barriers. Shannon index of diversity value (3.23) in the present study was comparable with the values of other Myristica swamps $\left(2.15^{6}, 3.69^{4}\right)$. When we enumerated Shannon diversity index separately for the five plots along stream side and away from it, the $t$ test shows statistically significant difference between Shannon's diversity indices of first plot (streamside) and that of others (away from the stream) which might be due to the swampiness where only few species can adapt and survive (Table 3 ).

The Simpson's index of species dominance shows high value when comparing to the nearest semi-evergreen and evergreen forests ${ }^{25}$. It can be expected due to the lower diversity and over dominance of the species of Myristicaceae, which are highly adapted to such an environment. The similarity index ${ }^{26}$ has been applied to test how the vegetation along streamside is differing from the vegetation away from it. The results shows that the first plot which was near to stream side and the last plot which was away from the stream is sharing only
$33 \%$ vegetation as common which further support the clear difference in species composition and distribution pattern along streamside and that of away from it.

\section{Girth class distribution and regeneration pattern}

The girth class shows a normal distribution pattern and (Figure 1) except a decrease in the recent past (gbh $10.1-30.0 \mathrm{~cm}$ ), where Knema attenuata get reduced its number from 60 to 30 when comparison is made between two lower girth classes $(10.1-30.0 \mathrm{~cm}$ and $30.1-60 \mathrm{~cm})$. Since it is a conserved area as sacred grove and there was no sign of human disturbance such as pole cutting this reduction in lower girth class may be attributed to other species specific factors which need detailed studies. To add on that, when we analysed the girth class distribution pattern of two dominant species it clearly indicates that in lower girth class Knema shows poor regeneration while that of Myristica remains normal (Figure 2). This indicates there may be an increase in the swampy area in recent past by which the area becomes more suitable for species like Myristica comparing to Knema. The current study also proved that Knema prefer non-swampy areas (Figure 3) and it could not establish in high water content. As far as seedlings are concerned, regeneration is quite good even though the density

\section{Girth Class Distribution}

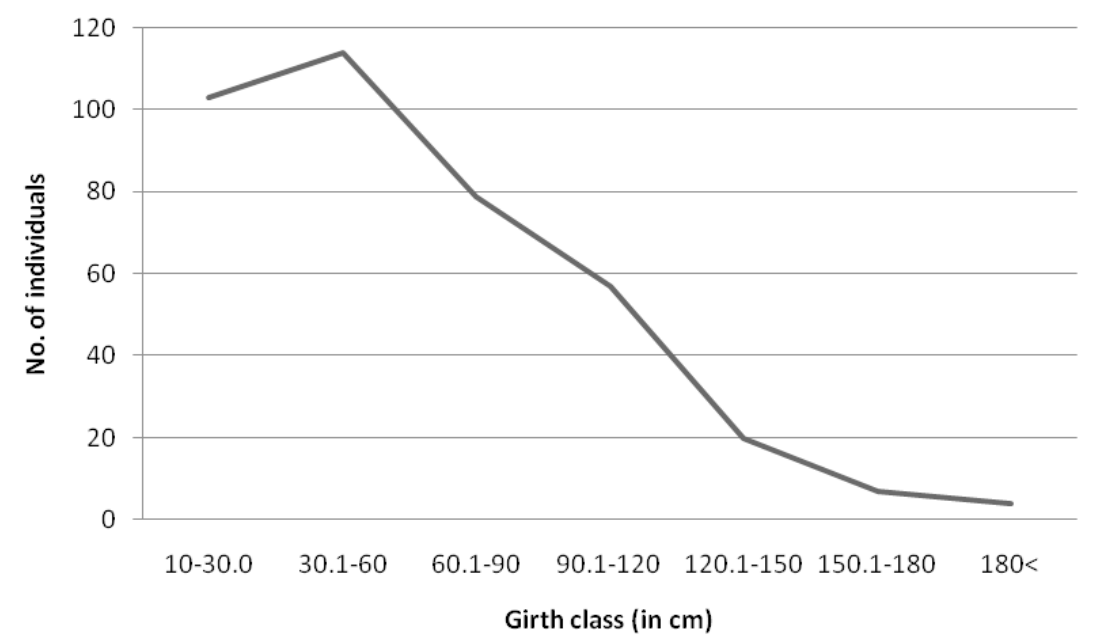

Fig. 1: Girth Class Distribution of individuals $(\mathrm{Gbh} \geq 10.0 \mathrm{~cm})$ in the study area 
shows medium value (7033 $\mathrm{ha}^{-1}$ ) when compared to the studies of Chandrashekara and Jayaram ${ }^{25}$ in semi-evergreen forests ranging from $4199 \mathrm{ha}^{-1}$ to $5866 \mathrm{ha}^{-1}$ and evergreen forest plots $(11,932$ $\left.\mathrm{ha}^{-1}\right)$ near to the present study area. As we cannot expect a high density of seedling as in the case of non-swampy forests, since the swampy conditions may not support good regeneration except in few species suitable to swamps.

\section{Distribution pattern of different species}

The study on the distribution pattern of species by analyzing the result of plots in swamp (Plot 1) and subsequent 4 plots (Plot 2-5) away from it, indicated that the number of individuals of two dominant species are vary. The two dominant species Knema attenuata and Myristica malabarica are just opposite in their pattern of distribution (Figure 3 and Table 4). Among first dominant species Knema attenuata, out of 139 individuals (gbh $\geq$ $10.1 \mathrm{~cm}$ ) recorded, 110 were concentrated in last 3 plots, which are away from the swamp. While the second dominant species Myristica malabarica prefer swampy areas in which out of 103 individuals ( $\mathrm{gbh} \geq 10.1 \mathrm{~cm}$ ), 81 were concentrated in the first two plots along streamside (Figure 3 and Table 4). As far as other species are concerned Holigarna arnottiana, Elaeocarpus tuberculatus, Mastixia

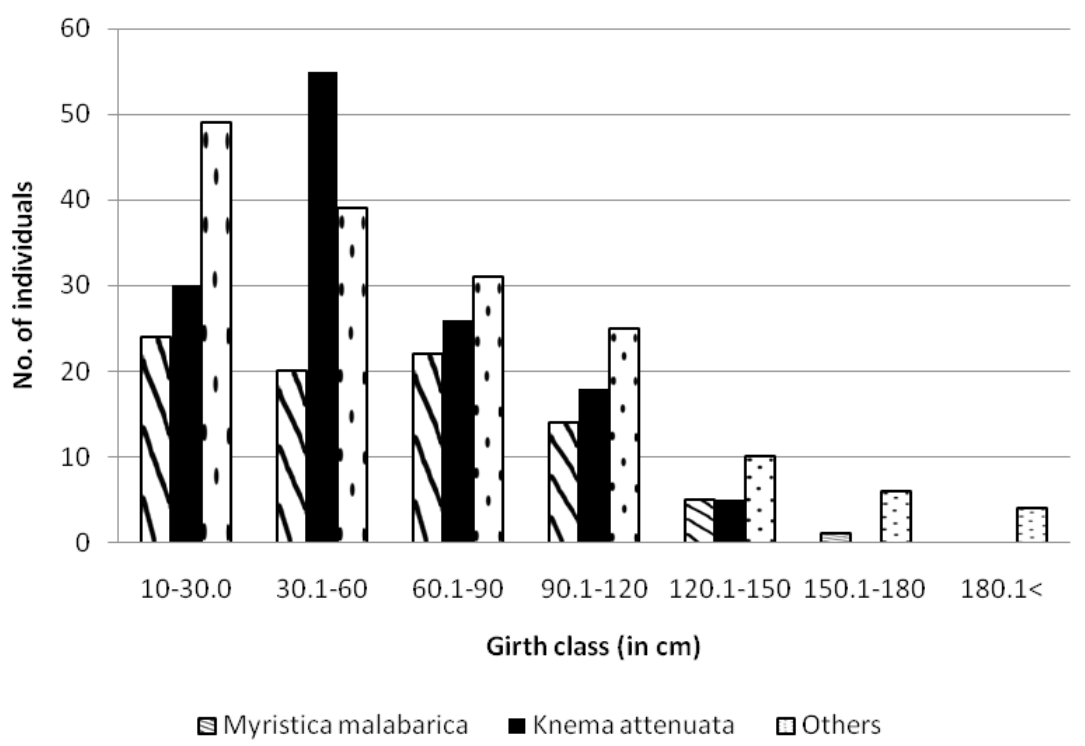

Fig. 2: Girth class distribution pattern of trees with special refrence to Myristica and Knema

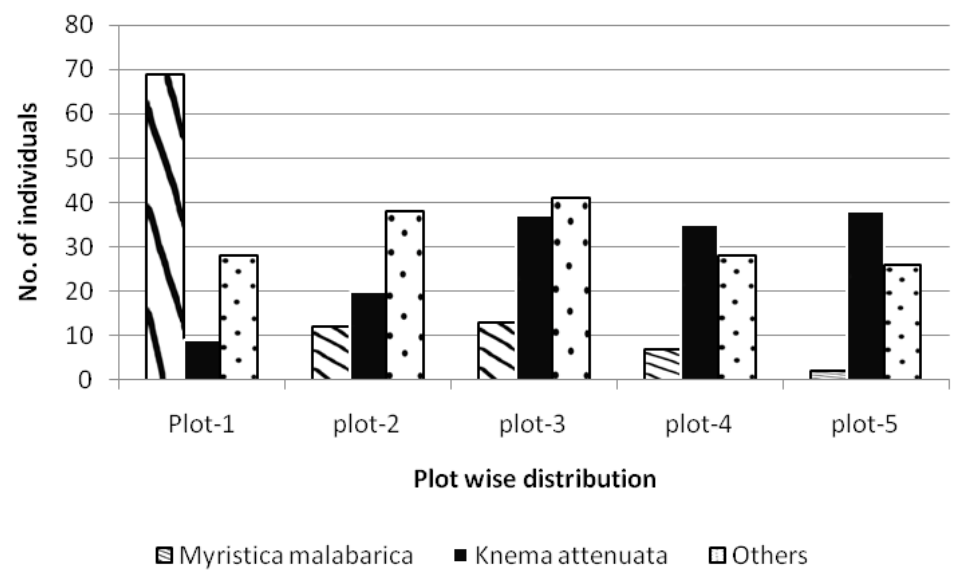

Fig. 3: Plot wise distribution of individuals with special reference to Myristica and Knema 
arborea and Hydnocarpus pentandra prefer swampy areas while Artocarpus hirsutus, Polyalthia fragrans, Diospyros bourdillonii, Hopea parviflora, Alstonia scholaris, Aglaia elaeagnoidea and Actinodaphne hookeriana prefer to keep distance from the stream. As far as the percentage frequency (individuals of gbh $\geq 10.1 \mathrm{~cm}$ ) is concerned Knema attenuata is present in 41 quadrats while Myristica malabarica

Table 1: Vegetation analysis of the study area

\begin{tabular}{|c|c|c|c|c|}
\hline Species & $\begin{array}{c}\text { Density } \\
\text { (individuals ha-1) }\end{array}$ & Frequency & $\begin{array}{c}\text { Basal Area } \\
\left(\mathrm{m} 2 \mathrm{ha}^{-1}\right)\end{array}$ & $\begin{array}{l}\text { Importance } \\
\text { Value Index }\end{array}$ \\
\hline Actinodaphne hookeri Meisn. & 4 & 4 & 0.07 & 1.71 \\
\hline Aglaia lawii (Wight) C. J. Saldanha & 16 & 14 & 0.518 & 7.02 \\
\hline Alstonia scholaris (L.) R. Br. & 28 & 20 & 0.701 & 10.54 \\
\hline Aporusa lindleyana (Gaertn.) Merr. & 10 & 10 & 0.173 & 4.26 \\
\hline Artocarpus hirsutus Lam. & 18 & 16 & 1.454 & 10.5 \\
\hline Cinnamomum malabatrum (Burm. f.) & 8 & 8 & 0.56 & 4.64 \\
\hline \multicolumn{5}{|l|}{ Blume } \\
\hline Diospyros bourdillonii Brandis & 32 & 20 & 0.197 & 9.57 \\
\hline Diospyros oocarpa Thw. & 4 & 4 & 0.254 & 2.24 \\
\hline Elaeocarpus tuberculatus Roxb. & 14 & 12 & 1.304 & 8.56 \\
\hline Ficus nervosa Heyne ex Roth & 6 & 6 & 0.123 & 2.61 \\
\hline Holigarna arnottiana Hook. & 82 & 46 & 4.37 & 34.49 \\
\hline Hopea parviflora Bedd. & 20 & 18 & 1.783 & 12.21 \\
\hline Hydnocarpus pentandra (Buch.-Ham.) & 10 & 10 & 1.256 & 7.42 \\
\hline \multicolumn{5}{|l|}{ Oken } \\
\hline Ixora nigricans $\mathrm{R}$. Br. ex Wight \& Arn. & 8 & 8 & 0.691 & 5.02 \\
\hline Knema attenuate (Hook. f. \& Thoms.) Warb. & 278 & 82 & 8.684 & 80.45 \\
\hline Lophopetalum wightianum Arn. & 2 & 2 & 0.003 & 0.76 \\
\hline $\begin{array}{l}\text { Mallotus philippensis (Lam.) Muell.- } \\
\text { Arg. }\end{array}$ & 2 & 2 & 0.01 & 0.78 \\
\hline Mangifera indica L. & 2 & 2 & 0.133 & 1.14 \\
\hline Myristica malabarica Lam. & 206 & 62 & 7.764 & 64.09 \\
\hline Persea macrantha (Nees) Kosterm. & 2 & 2 & 0.192 & 1.31 \\
\hline Polyalthia fragrans (Dalz.) Bedd. & 24 & 20 & 1.53 & 12.47 \\
\hline Prunus ceylanica (Wight) Miq. & 6 & 6 & 0.331 & 3.22 \\
\hline Pterospermum reticulatum Wight \& Arn. & 2 & 2 & 0.089 & 1.01 \\
\hline Sterculia guttata Roxb. ex DC. & 2 & 2 & 0.017 & 0.8 \\
\hline Symplocos racemosa Roxb. & 8 & 8 & 0.399 & 4.17 \\
\hline Syzygium mundagam (Bourd.) Chithra & 6 & 6 & 1.171 & 5.67 \\
\hline Turpinia malabarica Gamble & 4 & 4 & 0.334 & 2.48 \\
\hline Vitex altissima L.f. & 2 & 2 & 0.042 & 0.87 \\
\hline
\end{tabular}

Table 2: Basic information on vegetation with respect to tree community in the study area

\begin{tabular}{lcccc}
\hline $\begin{array}{l}\text { No. of } \\
\text { Species }\end{array}$ & $\begin{array}{c}\text { Density } \\
(\text { individuals ha-1) }\end{array}$ & $\begin{array}{c}\text { Basal area } \\
\left(\mathbf{m}^{2} / \mathrm{ha}\right)\end{array}$ & $\begin{array}{c}\text { Shannon Index } \\
\text { of Diversity }\end{array}$ & $\begin{array}{c}\text { Simpson Index } \\
\text { of Dominance }\end{array}$ \\
\hline 29 & 806 & 34.25 & 3.23 & 0.1906 \\
\hline
\end{tabular}


Table 3: Shannon Index of Species Diversity values for the study area

\begin{tabular}{lllll}
\hline Plot 1 & Plot 2 & Plot 3 & Plot 4 & Plot 5 \\
\hline $1.152^{\mathrm{a}}$ & $2.48^{\mathrm{bc}}$ & $2.12^{\mathrm{bc}}$ & $1.90^{\text {cd }}$ & $1.88^{\mathrm{d}}$ \\
\hline
\end{tabular}

Values superscripted by same letter not shows statically significant difference $(0.05 \%$ level) present only in 28 and Holigarna arnottiana in 23 quadrats, out of total number of 50 quadrats studied. All other species are restricted to a maximum of 10 quadrats. When we study the distribution of tree seedlings by dividing the five plots $\left(5000 \mathrm{~m}^{2}\right)$ in to two blocks each of $2500 \mathrm{~m}^{2}$ size the first one nearer to stream and other away from it, nearly $65 \%$ of these seedlings were distributed away from the swamp. Poor number of seedlings nearer to swamp

Table 4: Distribution pattern of dominant species from stream side (Plot 1) to away from it (Plot 5)

\begin{tabular}{lccccc}
\hline \multirow{2}{*}{ Species } & \multicolumn{4}{c}{ Number of individuals } \\
& Plot 1 & Plot 2 & Plot 3 & Plot 4 & Plot 5 \\
& & & & \\
\hline $\begin{array}{l}\text { Myristica malabarica } \\
\text { Knema attenuata }\end{array}$ & $59 \pm 3^{\mathrm{a}}$ & $9 \pm 2^{\mathrm{b}}$ & $12 \pm 1^{\mathrm{b}}$ & $5 \pm 0.5^{\mathrm{c}}$ & $1.5 \pm 0.1^{\mathrm{d}}$ \\
& & $17 \pm 1^{\mathrm{b}}$ & $35 \pm 2^{\mathrm{c}}$ & $32 \pm 1^{\mathrm{c}}$ & $35 \pm 1^{\mathrm{c}}$ \\
\hline
\end{tabular}

Values superscripted by same letter not shows statically significant difference (0.05\% level)

may be due to the presence water, knee roots etc which hamper the germination and establishment of seedlings. Another reason is that only few species like can ecologically and physiologically adapt to such swampy conditions. We could also notice that some species were restricted to the streamside while others away from it. Holigarna arnottiana, Elaeocarpus tuberculatus, Hopea parviflora and Vateria indica are totally restricted to first block which is nearer to stream while Olea dioica, Symplocos racemosa, Vitex altissima and Aporusa lindleyana are restricted to the second block. As in the mature phase, seedlings of two dominant species Myristica malabarica and Knema attenuata were also showed similar trends in their distribution. Only $5 \%$ of Myristica malabarica seedlings were distributed in the second block remaining were concentrated along streamside while $98 \%$ of the Knema attenuata were seen in the second block which is away from the stream side.

\section{CONCLUSION}

The study reveals that, the distribution pattern of different species in a myristica swamp is varying among dominant species. Among two dominant species, Knema attenuata prefer to keep a distance away from the stream which were widely distributed away from the stream while the other one Myristica malabarica were concentrated along the streamside. The sudden fall in the density of Knema attenuata in recent past indicates the increase in the swampiness of the study area and shows the effectiveness of the of the conservation measures undertaken by the local community and officials. Further species specific eco-physiological studies may also need in the restoration, conservation and management of myristica swamps of Western Ghats. 


\section{REFERENCES}

1. Krishnamoorthy, K., Myristica swamps in the evergreen forests of Travancore. Indian Forester, 86 (5): 314-315. (1960).

2. Champion, H. G., and Seth, S. K. A Revised Survey of the Forest Types of India. Manager of Publications, New Delhi, Page: 404 (1968).

3. Pascal, J. P., Wet evergreen forests of the Western Ghats of India. Inst. Fr. de Pondichery, Trav. Secti. Sci-Tech, Page: 547 (1988).

4. Varghese, A. V., and Kumar, B. M. Ecological observations in the fresh water swamp forests of southern Kerala, India. J. Trop. Forest. Sci, 9: 299- 314 (1997).

5. Varghese, A. O., and Menon, A. R. R. Assessment of Biodiversity of Peppara Wildlife Sanctuary, Trivandrum District, Kerala. J. Econ. Tax.Bot, 22 (3): 609-615. (1998).

6. Varghese, A. O., and Menon, A. R. R. Floristic composition, dynamics and diversity of Myristica swamp forets of southern Western Ghats, Kerala. The Indian Forester, 125 (8): 775-783 (1999).

7. Varghese, A. O., and Krishnamoorthy, Y. V. N. Application of geo-informatics for conservation and management of rare and threatened plant species. Current Science, 91(6): 762-769 (2006).

8. Bawa, K. S., Das, A., and Krishnaswamy, J. Western Ghats and Sri Lanka Biodiversity Hotspot Western Ghats Region. Critical Ecosystem Partnership Fund Conservation International 2011 Crystal Drive Suite 500 Arlington, VA 22202, USA (2007).

9. Joyce, J., Roby, T. J., Ramachandran, K. K., Swarupanandan, K., Thomas, P., and Nair, P. V. Biophysical characterization, conservation and management of a rare forest ecosystem, the Myristica swamps of Southern Kerala. In: The Proceedings of Second National Congress of the Western Ghats Forum at Coimbatore, Page: 9-11 (2007).

10. Induchoodan, N. C., Ecological studies of the sacred groves of Kerala. PhD thesis submitted to Central University, Pondichery (1998).

11. Chandrashekara, U. M., and Sreejith, K. A.
Possible impact of climate changes on tree species composition and diversity in lowland evergreen forests of Kerala, Western Ghats, Indian Forester, 129 (6): 770-775 (2003).

12. Jayarajan, M., Sacred Groves of Malabar. Kerala Research Programme on Local Level Development. Centre for Development studies, Thiruvananthapuram. Discussion paper. No. 92 (2004).

13. Ramesh, B. R., and Pascal, J. P. Atlas of the endemics of the Western Ghats (India), French Institute of Pondichery (1997).

14. Chandran, M. D. S., Mesta, D. K., and Naik, M. B. Inventorying and Conservation of the Myristica Swamps of Uttara Kannada. Report (Forest Research and Training Institute, Bangalore, Karnataka, India, Page: 162 (1999).

15. Gadgil, M., Krishnan, B. J., Ganeshaiah, K. N., Vijayan, V. S., Borges, R., and Sukamar, R. ENVIS Technical Report No. 16. Environmental Information System (ENVIS) Centre for Ecological Science Indian Institute of Science, Bangalore 560 012, India, Page: 14, 19, 27, 40-52, 81, 118 (2004).

16. Gururaja, K. V., Aravind, N. A., Ali, S., Ramachandra, T. V., Thirumalaisamy, P. V., Krishnakumar, V., and Aggarwal, R. K. A New Frog Species from the Central Western Ghats of India, and Its Phylogenetic Position. Zoological Science, 24: 525- 534 (2007).

17. Kumara, H. N., Pritham, N. S., Santhosh, K., Raj, V. V. M., and Anindya, SDecline of suitable habitats and conservation of the endangered lion-tailed macaque: land-cover change at a proposed protected area in SirsiHonnavara, Western Ghats, India. Current Science, 101 (3): 434-439 (2011).

18. Santhakumaran, L. N., Sing, A., and Thomas, V. T. Description of a scared grove in Goa (India), with notes on the unusual aerial roots produced by its vegetation. Wood, Page: 2428 (1995).

19. Mesta, D. K., Harsha, V., Upadhya, V., and Sanjiva, D. K. Burmannia championii Thwaites (Dioscoreales: Burmanniaceae), a new addition to the Flora of Karnataka. Journal of Threatened Taxa, 3(1): 1465-1468 (2011). 
20. Kershaw, K. A., Quantitative and dynamic plant ecology. Edward Arnold, London (1973).

21. Curtis, J.T., The vegetation of Wisconsion: an ordination of plant communities. University of Wiscosin Press, Madison, Wisconsin (1959).

22. Shannon, C. E., and Weaver, W. The mathematical Theory of communication. Urbana, Univ. Illinois Press, Page: 117 (1963).

23. Simpson, E. H., Measurement of diversity. Nature (London), Page: 163-188 (1949).

24. Chandran, M. D. S., and Mesta, D. On the conservation of the Myristica swamps of the Western Ghats. In U. Shaanker, R., Ganeshaiah, K. N. and K. S. Bawa (eds.) Forest Genetic Resources: Status, Threats and Conservation Strategies. Oxford \& IBH Publishing Co. Pvt. Ltd, Page: 1-19 (2001).

25. Chandrashekara, U. M., and Jayaraman, K. Stand structural diversity and dynamics in natural forests of Kerala. KFRI Research Report No. 232. Kerala Forest Research Institute Peechi- 680 653, Kerala (2002).

26. Sorenson, T., A method of establishing group of equal amplitude in plant sociology based similarity of the species. Content. Det. Kong Danske Vidensk. Selsk. Biol. Skr. (Copenhagen), 5 (4): 1-34 (1948). 